International Journal of Linguistics, Literature and Culture
Available online at https://sloap.org/journals/index.php/ijllc/
Vol. 5, No. 5, September 2019, pages: 15 22
ISSN: 2455-8028
https://doi.org/10.21744/ijllc.v5n5.730

\title{
Suicide Phenomenon on Bebandem Village: A Review on Religious and Socio-cultural
}

\author{
I Putu Gde Santika ${ }^{a}$ \\ Ida Bagus Gde Yudha Triguna ${ }^{b}$ \\ I Wayan Budi Utama ${ }^{c}$
}

\section{Article history:}

Received: 27 March 2019

Accepted: 31 July 2019

Published: 02 September 2019

\section{Keywords:}

bebandem;

cultural;

religious;

socio;

suicide;

\begin{abstract}
There is an ideational culture. It can be interpreted as a basis for thinking that the final reality is nonmaterial. It cannot be captured on eye-catching. The theory also stated that this world is seen as an illusion, and temporary or can be interpreted as an imperfect and incomplete aspect of reality. The next theory is the sensory culture theory. If the previous theory assumes that we must balance between the interests of the world and the hereafter, on the theory of sensory culture, on the contrary, we must be more oriented towards worldly interests. The material world experience with our senses is only reality that exists. The final theory is mixed culture theory. This theory is an affirmation between ideational and sensory theory. The theories are used to explain the causes of related suicide to sensate culture. The cultural dynamic theory was chosen as one of the cornerstones of this research. Due to the theory is consists of types of cultural mentality. Thus, this theory is used to explain the cultural conditions and situations that occur in Bebandem Village and the conditions and situations experienced by individuals who commit suicide through interviews, observation and so forth. Data collected are observation techniques, in-depth interviews, and document study techniques.
\end{abstract}

2455-8028 ${ }^{\circledR}$ Copyright 2019. The Author. This is an open-access article under the CC BY-SA license (https://creativecommons.org/licenses/by-sa/4.0/) All rights reserved.

\section{Author correspondence: \\ I Putu Gde Santika, \\ Universitas Hindu Indonesia, Denpasar, Indonesia. \\ Email address: santika.putugede@gmail.com}

\section{Introduction}

The suicide case in Bali island became a story that might be traced to its origins. There is a historical story about the kings of Bali at those time will be accompanied by the mesatia ceremony at the king's cremation ceremony. Mesatia was a suicide from the king's wife (usually the youngest wife) who would plunge into the fire. Wherein, the

a Universitas Hindu Indonesia, Denpasar, Indonesia

${ }^{\mathrm{b}}$ Universitas Hindu Indonesia, Denpasar, Indonesia

${ }^{\mathrm{c}}$ Universitas Hindu Indonesia, Denpasar, Indonesia 
king's body was burning from a high stage. Likewise, in Bali, there was an incident called puputan. It was carried out during the struggle against the invaders (Agra et al., 2018; Wirawan, 2018). The fact of suicide also occurred in Bali which is known as heaven island and its religious community. The numbers of cases exist are indeed different, maybe depending on who recorded them. They were not reported or the data source was different.

The suicide cases noted is indeed not entirely accurate. The noted sources on suicide case were the information and documentation subdivision of the Bali police public relations division, Suryani Institute and the forensic section of sanglah hospital centre (RSUP) Denpasar. Suicide rates were obtained from the Directorate of General Criminal Investigation of the Bali Regional Police and the data shown are data from January 2014 to February 2018. The data is sequential for four years and two months is presented in Table 1.

Table 1

The number of regency/city suicide occurred in Bali Province

\begin{tabular}{|c|c|c|c|c|c|c|c|}
\hline \multirow{3}{*}{ No } & \multirow{3}{*}{ Regency/City } & \multicolumn{6}{|c|}{ Number of Suicide } \\
\hline & & \multirow{2}{*}{2014} & \multirow{2}{*}{2015} & \multirow{2}{*}{2016} & \multirow{2}{*}{2017} & \multicolumn{2}{|c|}{2018} \\
\hline & & & & & & January & February \\
\hline 1 & Buleleng & 28 & 11 & 10 & 9 & 2 & 0 \\
\hline 2 & Tabanan & 15 & 20 & 14 & 10 & 1 & 2 \\
\hline 3 & Gianyar & 13 & 11 & 12 & 8 & 0 & 1 \\
\hline 4 & Klungkung & 3 & 3 & 0 & 3 & 0 & 0 \\
\hline 5 & Bangli & 12 & 9 & 6 & 8 & 2 & 1 \\
\hline 6 & Karangasem & 29 & 28 & 12 & 11 & 4 & 2 \\
\hline 7 & Jembrana & 7 & 6 & 11 & 10 & 0 & 0 \\
\hline 8 & Badung & 8 & 8 & 2 & 0 & 0 & 0 \\
\hline 9 & Denpasar & 10 & 20 & 9 & 9 & 0 & 0 \\
\hline
\end{tabular}

(Source: Directorate of General Criminal Investigation of Bali Police, 2018)

The number of suicides has occurred in regencies/cities in Bali Province. It is presented in Figure 1. This might be useful to make it easier for readers to see the suicides ranking.

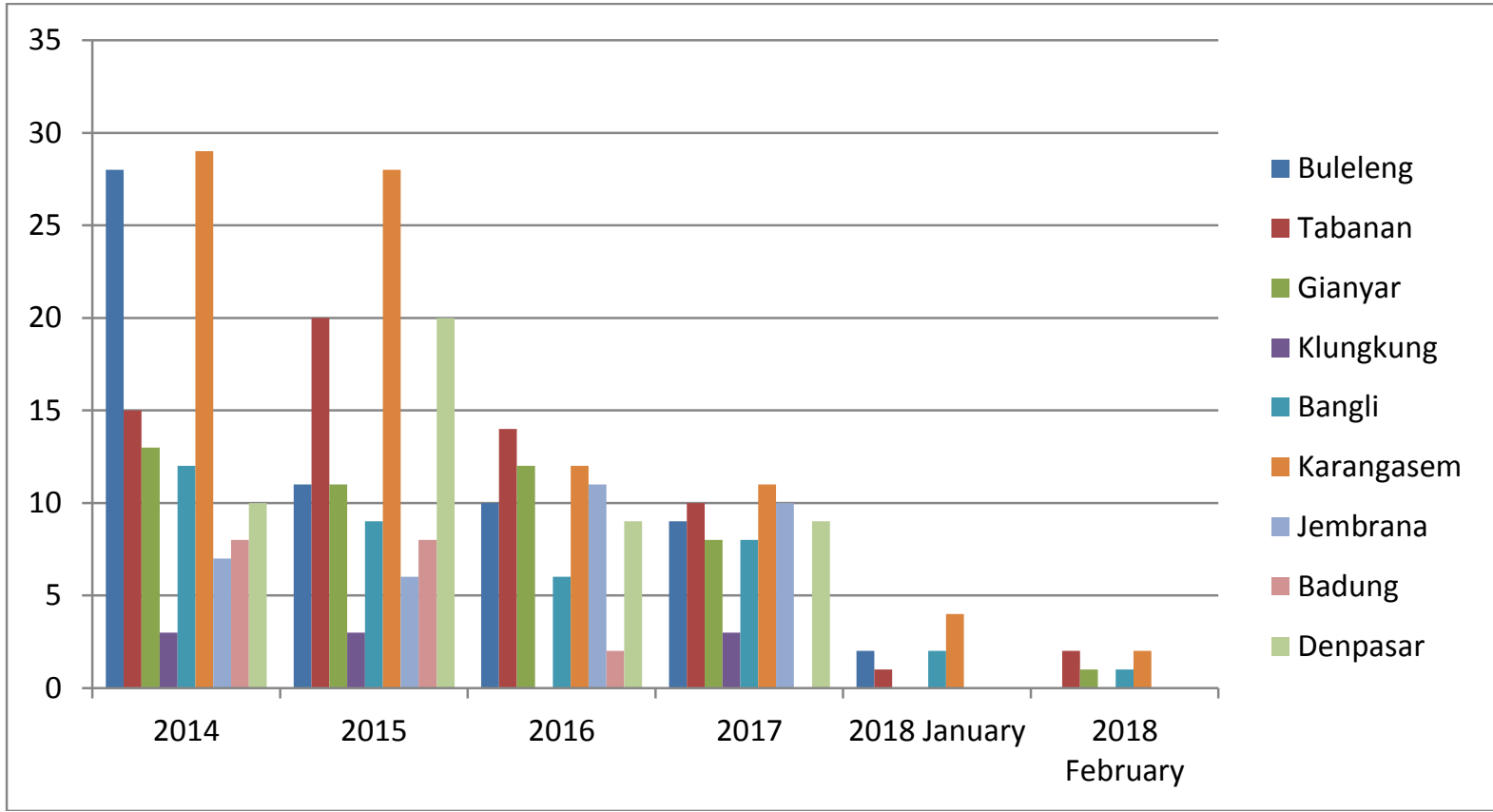

Figure 1. The number of suicides has occurred in regencies/cities in Bali Province 
The high suicides number in Bali is inversely proportional to Balinese beliefs about suicide. It is referred to as ngulah pati. This reality shows there is a gap between social texts and religious texts, between ideals contained in religious teachings and reality on life. The Hinduism teaching is adopted the majority of Balinese people. Suicide is considered a despicable act and has bad consequences for atma people who commit suicide. Suicide is death the wrong way. It is a grave sin. They died the wrong way, the body was not allowed to be taken home, immediately buried without being celebrated with a grave without gegumuk.

The development of the tourism world currently is termed as the tourism industry social changes began to occur in Bali (Mund, 2017; Suarda et al., 2018). The social change also changes the character and behavior of its inhabitants who were originally humanistic in character, possessed family-friendly traits, shared jokes and laughter. As time passed, the change is into an individualistic and materialistic society characterized waning family ties, triggering cases suicide case in Bali.

It can also be stated, the act of suicide can also due to an alienation situation (homeless). It is experienced by the Balinese at a time when kinship relations experience social destruction. It is in accordance with (Wikantoso 2016), homeless situations can occur due to loss of subjective awareness.

Karangasem Regency is at the eastern end of Bali Province, ranks highest in the suicide rate. Data can be taken starting in 2014 in Karangasem. There were 29 suicides in 2015. There were 28 suicides in 2016. There were 11 suicides and in 2017. There were 12 suicides in 2018. Data has only been noted for two months. It was not included.

Regarding the social aspect, it can be seen the location of Bebandem Village is not too remote. It is not far from Amlapura City. However, Bebandem Village is a very traditional village. The people are very strict in holding traditional values. The lives of the people majority are farmers, wetland farmers, farmer farmers, sharecroppers, farm laborers, and odd jobs. Even though, Bebandem Village has begun to be affected by touches of progress unlike, the emergence of franchised mini-market shops. It seems there are still many people living below the poverty line. It is related to the index from the central statistics office and the criteria of the ministry of social affairs. Having seen from the location of residence, many people who live rather remote in the huts. Similarly, having viewed from employment, social life, and income sources. Communities on peaceful social conditions and with a quiet life, why do suicide actions begin to appear in the people (Gepu et al., 2018; Rahmawati et al., 2018).

Regarding the cultural aspect, Bebandem Village is an old village. It is a relic of Ida Dalem Tarukan after Gelgel Palace. Bebandem Village is very firm in holding the cultural traditions of its ancestral heritage, for example, in the change of banjar staff. There is still firmly maintains a tradition. The staff is descended, meaning that the staff figures are only from certain family descendants. Likewise, for example, Banjar Adat Dukuh, there are awig-awig that regulate their citizens. Therefore, the ceremony of atiwa-tiwa in the grave or at the burial to mehulu kauh. Those are examples of cultural traditions still held firmly by residents in Bebandem Village.

Regarding the religion, the aspect can be seen in Bebandem Village. It is predominantly Hindu, the perseverance and obedience of Hindus in carrying out their religious rituals. The rituals are individual, regarded as extended family, as well as rituals at the dadia level and in traditional villages, namely in Tri Kayangan. All the descriptions shows are, of course, only from the outside views. Towards how true in the hearts of each people, only people who know (Kuri et al., 2018; Subawa et al., 2019).

Having seen the social conditions, cultural conditions, and religious conditions. A discussion with Kelian Adat Dukuh named Mr. I Wayan Karsana, the question arises, what exactly happened, why since the last two decades began to emerge many suicides in Bebandem Village. Therefore, the author finally decided to choose Bebandem Village as a research location.

The terms are to consider when discussing with Mr. I Wayan Karsana are: a). Suicide cases in Bebandem village are quite a lot. b). No one has ever examined these suicides in Bebandem Village. c). Bebandem Village is an old village. d). Bebandem Village is one of the villages that still hold traditional values. e). Bebandem Village is one of the villages that have begun to experience progress marked by the beginning of franchise shops. According to information from Kelian Adat Banjar Dukuh, Mr. I Wayan Karsana stated, it was only around the late 1990s. There were people committing suicide in Bebandem Village. Before the late 1990s, it was very rare to hear people commit suicide. There were precisely cases of violence, cases of fighting, and murder cases. The Bebandem Village people are the Hindus majority who are devout in carrying out their religious rituals. It can be seen from the perseverance of the people in conducting religious ceremonies. In the midst unlike, devout devotees carrying out their religious rituals, apparently, suicide cases have begun to emerge lately (Kawangung, 2019).

If it is synchronized the suicide data in Bebandem Village with the data that has been shown before. They do not seem to be synchronous. Perhaps, due to the data so far are not always synchronous. The data that the authors present

Santika, I. P. G., Triguna, I. B. G. Y., \& Utama, I. W. B. (2019). Suicide phenomenon on bebandem village: a review on religious and socio-cultural. International Journal of Linguistics, Literature and Culture, 5(5), 15-22.

https://doi.org/10.21744/ijllc.v5n5.730 
are data that the authors obtained through direct interviews with Kelian Banjar Dukuh, also with several local communities who were invited to the interview. The Number of suicides in Bebandem Village is presented in Table 2.

Table 2

The number of suicides occurred in Bebandem Village

\begin{tabular}{llllllllll}
\hline \multirow{2}{*}{ Village } & \multicolumn{10}{c}{ Number of Suicides (Year) } \\
\cline { 2 - 11 } & 2010 & 2011 & 2012 & 2013 & 2014 & 2015 & 2016 & 2017 & 2018 \\
\hline Bebandem & 1 & - & 2 & 2 & 1 & - & - & 2 & - \\
\hline
\end{tabular}

(Source: Bebandem Village Community, Karangasem)

There are three problems can be formulated in the present study. (1) Why the phenomenon of suicide occurred? (2) How the form of suicide committed by victims in terms of social and cultural and religious aspects? The last one is (3) How the implications can occur in people's lives if the suicides continue to occur in the Bebandem Village community?

\section{Materials and Methods}

Helping analyzed the research problem, the theory that was used is Deprivation Theory. The basic concept is individuals can experience a very deep disappointment. The disappointment occurs due to a mismatch between ideal expectations and the reality they face in social life.

The current study as well as is used Social Integration Theory. Emile Durkheim (1973), is one of the theorists who uses a sociological approach of studying the phenomenon of suicide. The suicides viewed from the perspective of social integration. Wherein, the changes in the level of social integration in society, if the organic solidarity decreases and the anomie level increases, the suicide rate tends to rise. A change in suicide rates reflects a state of solidarity in society. The basic proposition used that suicide rates vary according to the level of social integration.

The present research also used the Culture Dynamic Theory. Sorokin (2017), has contributed several theories including the theory of types of cultural mentality. The theory is key to understanding integrated cultural systems, namely using the theory of cultural mentality. It is explained that there are three types of cultural mentality.

It is an ideational culture. It can be interpreted as a basis for thinking that the final reality is nonmaterial. It cannot be captured on the eye. The theory also stated that this world is seen as an illusion, and temporary or can be interpreted as an imperfect and incomplete aspect of reality. The next theory is the sensory culture theory. If the previous theory assumes that we must balance between the interests of the world and the hereafter, on the theory of sensory culture, on the contrary, we must be more oriented towards worldly interests. The material world experience with our senses is only reality that exists. The final theory is mixed culture theory. This theory is an affirmation between ideational and sensory theory. The theories are used to explain the causes of related suicide to sensate culture.

The cultural dynamic theory was chosen as one of the cornerstones of this research. Due to the theory is consists of types of cultural mentality. Thus, this theory is used to explain the cultural conditions and situations that occur in Bebandem Village and the conditions and situations experienced by individuals who commit suicide through interviews, observation and so forth. Data collected are observation techniques, in-depth interviews, and document study techniques.

\section{Results and Discussions}

\section{Theoretical findings}

a) The findings obtained proved to strongly strengthen the theory of social integration about suicide because many factors were found to support the occurrence of suicide in Bebandem Village including, for example, the existence of loose social integration, factors of living in remote locations (isolated), living factors in poverty, the factor of living with a small family and perceived looseness of kinship. Therefore, it seems to 
strongly strengthen Durkheim's opinion about suicide. It is stated that, if people commit suicide, then the trigger will not be far from the factor of community and social stability.

b) This research turned out to be very supportive of Deprivation theory, Deprivation theory is a social theory supported by Thouless and Parsons, because in cases of suicide in Bebandem Village. There are many influencing factors in the form of chronic disease factors, chronic disappointment, and old age factor,

c) The additional findings on this study were also found in the form of perceived cultural pressure, a loose feeling of kinship, and a sense of cultural culture.

The cultural pressure began to be felt with the inclusion of formal religious institutions. They offer systems are different from the local culture. It can put pressure on the local population unlike, the uniformity of the grave direction. The uniformity of the direction of the tomb is contrary to local beliefs, putting pressure especially on the village elite. They feel unable to maintain ancestral advice.

The terms of the yadnya implementation unlike, the three-month mass ceremony. The past was never a problem which caused a case because social situations and conditions in the past could be carried out. It was handled with mutual cooperation by family, neighbors, and so forth. However, the present small yadnya can be felt like a cultural pressure because nowadays people are too busy and all-round counting.

Having found the cultural pressure, the existence of sensory culture and the looseness of kinship began to be felt, the community needs to start observing this phenomenon. It is not impossible the latest findings behind the day can emerge and threaten the noble values of the Balinese culture. Hopefully, the latest findings can move young researcher's hearts to explore.

\section{Practical findings}

The factors findings in this study were tried to be sorted. They could be seen which were actually called the underlying factors and actually acted as suicide factors.

a) Underlying factors

Referring to the underlying factors are the factors which have long been experienced, felt, and suffered by the victim before the commits suicide. In these suicides, there are factors underlying the occurrence of these suicidal events. The factors include the existence of loose social integration, the existence of living factors in isolation, the existence of poverty factors, the existence of factors pain factors that do not heal with old age. There are deprivation factors. Lately, there have also begun to be felt factors of cultural pressure, sensory cultural factors, and factors of looseness of kinship have begun to be felt.

b. Precipitating factors

What is meant on precipitating factors are factors that trigger a person to commit acts of desperation such as suicide. The trigger factors are of various types and are individual in nature. For example, people who are chronically ill and often feel hopeless about their pain, when they are taken for treatment. They feel stressed because they may feel that they will not heal, then commit suicide. People accused of stealing, because they feel do not steal, feel like they are poor and without relatives. They feel that no one will defend and then commit suicide. An individual who lives in poverty at the time of holding traditional work on a quarterly basis. Due they do not have enough money to spend, feels stressed, and then kills himself.

\section{Conclusion}

Based on the field research results and data analysis of suicide perpetrators in-depth studied in Bebandem Village, Bebandem Subdistrict, Karangasem Regency, it can be concluded as follows:

1) It is obtained the facts underlying the occurrence of suicides as follows, for example, the role of social factors, cultural factors, and the possibility of a lack of understanding of the teachings of his religion. It is accompanied on losing social integration factors, alienation factors, poverty factors, chronic disease factors, deprivation factors, cultural pressure factors. There has begun to be a sense of sensory culture and the loosening of kinship, although it has no direct effect.

2) The type of suicide obtained in this study is the type of egoistic suicide, according to the classification of suicide types from Durkheim. If we look at this type of suicide, it can be concluded that all suicides are in accordance with Durkheim's social integration theory. Regarding the results of observations and interviews in

Santika, I. P. G., Triguna, I. B. G. Y., \& Utama, I. W. B. (2019). Suicide phenomenon on bebandem village: a review on religious and socio-cultural. International Journal of Linguistics, Literature and Culture, 5(5), 15-22.

https://doi.org/10.21744/ijllc.v5n5.730 
the field, the form of suicide is suicide by hanging and suicide by jumping into a dam. Suicide occurs according to social review is egoistic suicide that occurs due to loose social integration, while from cultural review. There is cultural pressure has a large influence role as well as from religious review, possibly due to the lack of deep understanding of religion and the occurrence of spiritual emptiness and suffering.

3) The implications occur due to the occurrence of suicides in Bebandem Village are social implications. Wherein, the suicide can continue to increase because the community considers it to be a normal thing. Cultural implications, it is far suicide is considered a very taboo. However, if the left unchecked for a long time understanding suicide is taboo and sinful will become blurred. Implications for religious aspects, the longer the understanding of the people about the nature of how noble to be born as a human being, the understanding of the nature of life as a human being, understanding of the nature of death and understanding of the implementation of ceremonies for the dead will be increasingly blurred.

\section{Suggestions}

There some suggestions are for the following:

a) Suggestions for each individual. To each individual/manners are expected to maintain good relations in accordance with the concept of Tri Hita Karana. Good relationship up, sideways, and down. Upward, in this case, is to maintain a sense of devotion to the presence of Ida Sang Hyang Widhi Wasa (God). To the side in this case maintaining good relations with fellow humans, in order to maintain kinship. Maintaining social integration with fellow human beings. Down, in this case, is maintaining harmony in relations with sociocultural changes, hope that they can adapt quickly to changes.

b) Suggestions for banjar adat or banjar dinas. It is recommended to them in terms of prevention, the role of the banjar is very important, perhaps the main role of the traditional banjar, with a lecture. It is to immediately make regulation about the ceremonial procedure for the dead person to admit starch which is certainly not the same as the death ceremony for the dead reasonable.

c) Suggestions to the desa adat or desa dinas. It is recommended them may need to create a crisis center for suicide on working with the Puskesmas. This is an example made in Gunungkidul Regency, Yogyakarta. If there are panic residents, this is a telephone number that can be contacted to simply pour out their panic. Therefore, suicide can be prevented. Desa adat might also be able to draft awig-awig about the suicide prohibition with all the traditional sanctions. Because in fact, suicide is very contrary to religion and is a great sin.

d) Suggestions to the government. It is recommended to the government to be more intensive in giving lectures either through social services or health services or from the department of religion, about the suicide prohibition.

e) Suggestions to public institutions/religious leaders and Sulinggih. It is recommended to public institutions, religious leaders, sulinggih (priest), in preventing suicide cases that their role could be increased. It is not solely in the ceremony alone. It may also need to further enhance the dharma wacana can suppress the case of suicide.

f. Suggestions for preventing implications. The advice is conveyed to all parties. Therefore, all have a role in preventing the implications occur after a suicide, the implications for social aspects, cultural aspects, and religious aspects, this requires a synergistic role, both from individual figures, traditional leaders, religious leaders, and official government officials. For all to play a role in giving enlightening lectures about life and this life. The official government institutions, social institutions, PHDI, sekehe dadia, sekehe santi, need to be more active in giving enlightenment about religion through the dharma wacana or dharma tula.

\section{Conflict of interest statement}

The authors declared that they have no competing interest.

\section{Statement of authorship}

The authors have a responsibility for the conception and design of the study. The authors have approved the final article.

\section{Acknowledgments}

The authors would like to thank the editor of IJLLC for their valuable time, support, and advice on completing the current study. 


\section{References}

Agra, I. B., Gelgel, I. P., \& Dharmika, I. B. (2018). Pressure on socio-cultural towards post-divorce Hindu women in Denpasar city. International Journal of Social Sciences and Humanities, 2(3), 63-78. https://doi.org/10.29332/ijssh.v2n3.191

Durkheim, E. (1973). Emile Durkheim on morality and society. University of Chicago Press.

Gepu, W., Suda, I. K., \& Suyasa, I. M. (2018). Religious conversion towards Hindu Kaharingan to Christianity. International Journal of Linguistics, Literature and Culture, 4(4), 25-37. https://doi.org/10.21744/ijllc.v4n4.257

Kawangung, Y. (2019). Religious moderation discourse in plurality of social harmony in Indonesia. International Journal of Social Sciences and Humanities, 3(1), 160-170. https://doi.org/10.29332/ijssh.v3n1.277

Kuri, -, Gelgel, I. P., \& Utama, I. W. B. (2018). Basir in religious system of Dayak Hindu Kaharingan society. International Journal of Social Sciences and Humanities, 2(2), 164-174. https://doi.org/10.29332/ijssh.v2n2.159

Mund, P. (2017). Hardiness and culture: a study with reference to 3 Cs of Kobasa. International Research Journal of Management, IT and Social Sciences, 4(2), 152-159.

Rahmawati, N. N., Kumbara, A., \& Suda, I. K. (2018). Multiculturalism towards religious life in tewang tampang village: moral education implementation based local wisdom. International Journal of Linguistics, Literature and Culture, 4(6), 63-71. https://doi.org/10.21744/ijllc.v4n6.408

Sorokin, P. (2017). Social and cultural dynamics: A study of change in major systems of art, truth, ethics, law and social relationships. Routledge. https://doi.org/10.4324/9781315129433

Suarda, I. W., Yadnyawati, I. A. G., \& Suda, I. K. (2018). Portrait of Hindu religious teacher performance certified educator in junior high schools Denpasar. International Research Journal of Management, IT and Social Sciences, 5(3), 53-61.

Subawa, I. B., Gelgel, I. P., \& Subrata, I. W. (2019). Existence of Bali Aga community religion. International Journal of Social Sciences and Humanities, 3(1), 72-81. https://doi.org/10.29332/ijssh.v3n1.256

Wikantoso, B. (2016). Konsep Intersubjektivitas dalam Phenomenology Of Spirit Karya Gwf Hegel. DHARMASMRTI: Jurnal Ilmu Agama dan Kebudayaan, 15(28), 67-90.

Wirawan, I. W. A. (2018). Maintaining social relationship of Balinese and Sasak ethnic community. International Journal of Social Sciences and Humanities, 2(1), 92-104. https://doi.org/10.29332/ijssh.v2n1.96

Santika, I. P. G., Triguna, I. B. G. Y., \& Utama, I. W. B. (2019). Suicide phenomenon on bebandem village: a review on religious and socio-cultural. International Journal of Linguistics, Literature and Culture, 5(5), 15-22. 


\section{Biography of Authors}

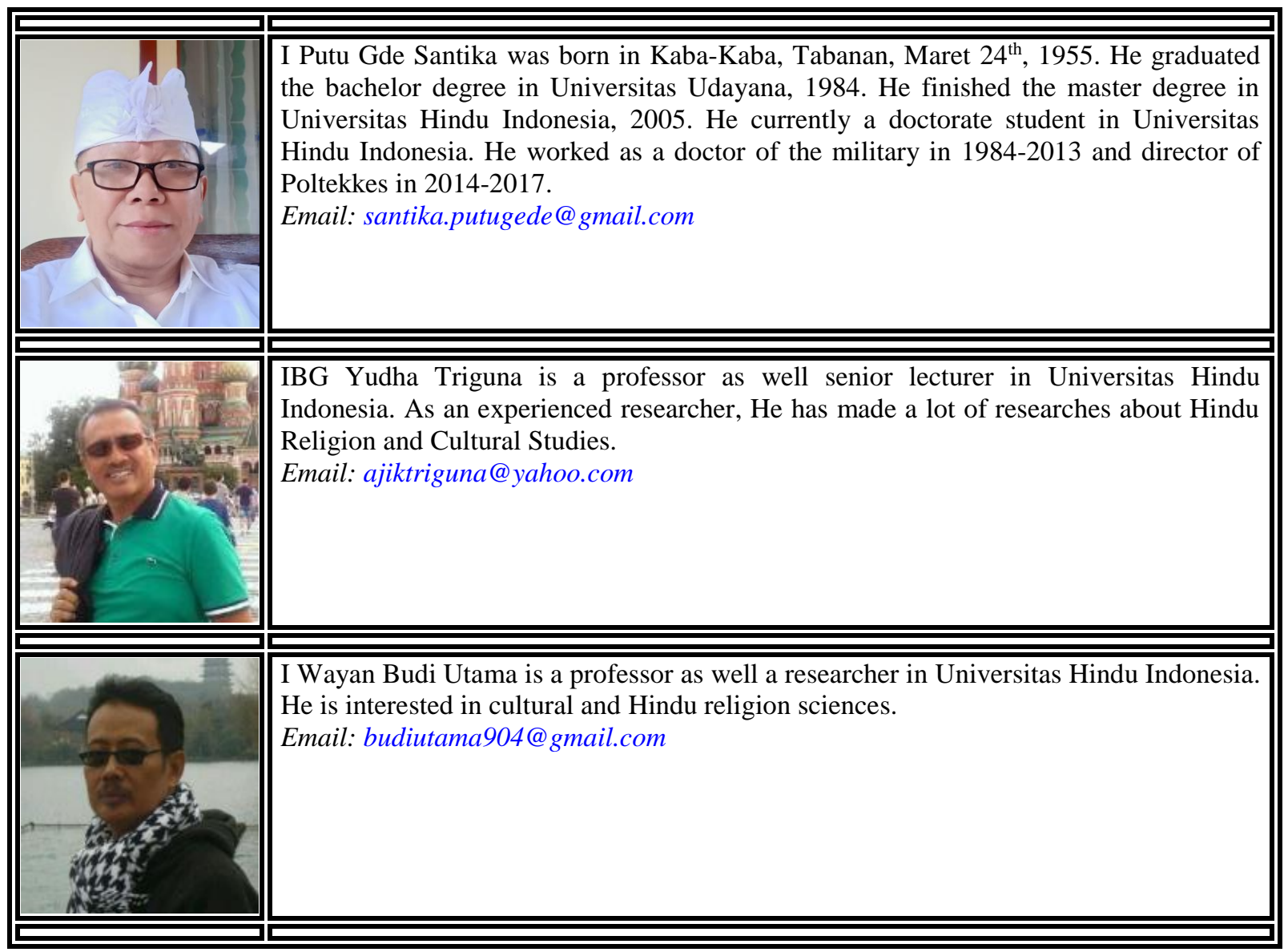

